\title{
Sex as a Weapon to Settle Scores against Dalits: A Quotidian Phenomenon
}

\author{
Jyoti Diwakar'
}

\begin{abstract}
In the Indian context, caste controls the gender norms as women are producers of the notion of 'caste purity'. Historically, the violation of caste codes including those related to women have been subjected to punishment through the instrument of social ostracism. Dalit men and women have been encountering culturally sanctioned violence, from higher caste people in the name of 'violating social norms' such as temple entry, untouchability, intercaste marriages, and so on. As a result, Dalits, especially women become easy targets for the 'guardians of social authority'. Sadly, larger majority of Hindus remain immune to the occurrence of violence against Dalits. This article aims to address sexual violence, specifically rapes of Dalit women due to their intersectional position in the society. It explores the responses of state machinery on two case studies: Bhagana (2014) and Alwar (2019), wherein Dalit women's rapes expose the power wielded by dominant caste communities. The paper shows the use of rape as an apparatus to humiliate a community and family in cases of land disputes involving Dalit farmers.
\end{abstract}

\section{Keywords}

Rape, Dalit women, caste, sexuality, power, sexual violence

\section{Introduction}

Dalits, with their total number estimated to be 16.6 percent of the Indian population (Census of India, 2011) experience a disproportionate share of its socio-economic burdens. Arguably, it is only Dalits (constitutionally known as scheduled caste), who continue to suffer the traumatic legacy of the most humiliating social degradation inflicted on them through the centuries-old tradition of untouchability

\footnotetext{
'Doctoral Candidate, Department of Political Science,

Faculty of Social Science, University of Delhi, Delhi-I 10007

E-mail: jyotidiwkar36@gmail.com
}

(C) 2020 Jyoti Diwakar. This is an open access article distributed under the terms of the Creative Commons Attribution License, which permits unrestricted use, distribution, and reproduction in any medium, provided the original author(s) and source are credited. 
through casteism. Despite all the constitutional safeguards as well as the enactment of several laws to support women's honour and dignity, the strong impact of caste even on the judicial system has been seen across the country on several occasions. Inequality of resources, opportunity, and discriminatory treatment towards Dalit women is the prime cause of their vulnerability and social exclusion in society. Since exclusion is both the cause and consequence of the deeply divided Indian society, it is important to understand how religion, caste, gender, class, ethnicity, and region based identities and status could become a possible source of instigation of violence. Thus, identity plays a significant role while interrogating the violence perpetuated against Dalit (ex-untouchable) men and women due to their caste position in society. In India, caste has been defined in several means and modes, one of which is that "caste system is marked not merely by inequality but is affected by the system of graded inequality" The Caste system involve division of Hindus with graded inequality in economic, social and cultural rights.As we go down in caste hierarchy from Brahmin to the unouchbales the rights get reduced, and the untouchables who are located at the bottom of caste hierarchy practically have no rights except to serve the castes above them. The women irrespective of caste particularly suffered the most from denial of rights..In this sequence of graded inequality the untouchables women suffered the most. (Dr. Babasaheb Ambedkar Writing and Speeches 2014 p. 167) Ambedkar further observed that 'caste originated and developed through reproduction in an organized manner, control and excessive violence over women's sexuality, and legitimate control over such practices through ideology in an intra-group process' (Rege, 2013, p. 61). John Gultang (1990) has emphasized on the role of ideology in instigating violence. In all this dynamic changes, although caste has undergone changes, its core feature of greaded inequality, particularly related to women and their sexutally through Hindu religious practices. has remained without much change.

The issue of violence against women needs to be scrutinized with utmost priority so as to develop an adequate strategy and initiatives to curb such incidents. Violence should be understood through its structural causes such as 'Brahminical patriarchy' (Chakravarti, 1993). Such construction is needed to look for strategic solutions on violence against women as deeper examination reveals that acts of sexual violence comprise both caste ideology and misogynistic attitude. They are more likely to happen when the focus of violence is upon toxic masculinity wherein men generally perpetrate violence on women. However, it does not mean that women are incapable of indulging in violent activities or restraining themselves from instigating violence. The social construction of masculinity and femininity gives ground to justify male violence due to the patriarchal structure. Ironically, due to such justifications and notions, many feminist groups in India consider patriarchy as the sole reason for violence heaped on women. It is primarily due to such narrowed conclusions of violence on women that the literature of Indian feminist framework has not been able to capture a better picture of violence on Dalit women (Darapuri, 2017, p. 441-42).

In comparison to the mainstream literature on sexual crimes against women, there are fewer studies that capture the plight of Dalit women. The few examples include ethnographical and autobiographical works based on socio-anthropological research (Paik, 2018, p.2). However, considering the way Dalit women have been overburdened by 'intersecting technologies' of caste, class, gender, sexuality, and community, it clearly makes their condition different from their non-Dalit counterparts (Ibid). Therefore, the caste and community oppression are an immediate addressable 
followed by their socio-economic position in society. Further, Dalit women are involved in different occupations because of their structural location in the Indian social order. They have been forced into hazardous occupations such as excreta cleaning, cleaning of dead animals, piggery, butchery, and cleaning of soiled clothes, etc. (Kumar, 2020, p. 144-45). In addition to these persisting factors, Dalit women are easily accessible, affordable, and available to such occupations to the dominant caste. Also, the dependency of Dalit women on the perpetrator's dominant castes leads to an unwelcome culture of violence and silence (Aloysius, Mangubhai, \& Lee, 2011, p. 3). Therefore, it is necessary to distinguish the 'homogenous' category of 'Indian woman' and the nature of violence against her from the poles apart experiences and position of the Dalit woman.

Women encounter violence across caste and class in the urban context. In the rural context, Dalit women face collective, physical, and sexual atrocities publicly on a regular basis. These function as a means to 'punish' Dalit women and men for asserting their rights against the caste hierarchy. Most of such acts (murder, gang rape, and naked parade, etc.) have a telling effect on the psyche of Dalits as a whole, and women in particular. This structure of violence makes them 'easy prey' to the lust and wrath of upper-caste men (Arya \& Rathore, 2019, p. 8-9). Such incidents are supposed to be reflective of collective weakness, sense of insecurity and vulnerability of the marginalized community, and is particularly targeted against their men, who are considered 'incapable' of protecting their women from men of dominant castes. The obvious question that is raised by many scholars is why do such incidents frequently occur against Dalit women in rural areas? The larger civil society, media, and social activists seldom focus on their plight.

As the aforementioned arguments and questions communicate that caste difference, experiences and location become a subject of inquiry for violence on Dalit women. The location of the victim and the background of the offender convey the intensity of violence and the overall impact, it makes as an event, as a process, or an everyday experience of someone's life. In the Indian context, violence on women is regulated through their social position as well as the civil society's reaction to it. One cannot assume that rape is just a matter of sexual desire; it is an affirmation that women are objects of pleasure; on many occasions the ground for revenge. In a collective sense, rape has explicitly been used as a political act with collective aggression, and become a spectacular ritual-- that of victory against the enemy community (Agrawal, 2012, p. 259). The semiotic expression of the sexuality of upper caste and lower caste women needs to be explored in the context of sexual violence on Dalit women. Likewise, nonDalit women rape cases such as the Nirbhaya case in Delhi (2012) and Priyanka Reddy case in Telangana (2019) divulge the selective justice process from the state machinery and speedy procedure in comparison to other cases. Such cases have led to many protests against the Indian state. Because media, movies, and documentaries were made to reach these cases to the masses, it led to the perception of sympathy towards 'India's daughters'. In contrast, more horrendous incidents have occurred with Dalit women in Karamchedu (a village in Prakasam District) massacre in Andhra Pradesh (1985), Bhanwari Devi in Rajasthan (1992), Shivapati (1994), Anita Kumari in Uttar Pradesh (2003), Khairlanji (a village in Bhandara District) in Maharashtra (2006), Mirchpur (a town in Hisar District) in Haryana (2010), Budaun in Uttar Pradesh (2014) and Satyabhama in Maharashtra (2015). According to the National Crime Records Bureau (NCRB) data, on an average four Dalit women are raped daily (Dutta, 2019). 
Ironically, NCRB data has huge gaps while enumerating rape cases; the 'principal offence' criteria mentions that a rape leading to death will be recorded as murder, not rape (All India Dalit Mahila Adhikar Manch [AIDMAM] \& National Campaign on Dalit Human Rights [NCDHR], 2018, p. 27). Such a criterion invisiblizes the heinous crime of rape. According to the National Family Health Survey data (NFHS 2015-16), 33.2 percent of SC women experience physical and sexual violence between the ages of 15-49 years in rural India Ibid, P-23. Surprisingly these cases have faded away from the sight of the state, and the media's efforts to reflect on causes of such incidents have instead proved counter productive for Dalit women.

Therefore, this paper aims to address the violence against Dalit women with reference to Bhagana Rape Case (2014) in Haryana, in which land became a contentious issue and rape was used as an apparatus to humiliate a community and family. This paper also examines another case in Rajasthan's Alwar district (2019) wherein a married Dalit woman was gang-raped in front of her husband. In this incident, the downtrodden status of Dalits allowed the dominant caste status of the perpetrator to commit violence. This was reflected in a statement of one of the offenders who said, 'What can a Dalit do to us?' (Dayal, 2019). This statement indicates the structure of supremacy and caste privileges enjoyed by offenders; they were obviously aware of the social hierarchy and apathy of the state machinery towards the marginalized sections.

\section{Social Prerogatives on the Un(touched) Dalit Women Body}

The continued violence against Dalits is arguably both an undeniable social fact and source of embarrassment for the state at the same time (Rao, 2011, p. 613). The Indian constitution abolished untouchability through Article 17, but upon witnessing the persistence of such practices, a set of affirmative action policies and laws were put in place to tackle the issues of continued atrocities on ex-untouchables. Such a system of 'compensatory discrimination' is undoubtedly a unique form of civil rights law and enables the understanding of caste and its structures of deprivation and impoverishment. Dalit women's personhood and integrity have been denied at multiple levels due to social hierarchies. As argued by Dr. B.R. Ambedkar, 'the origin of the caste system is associated with the mechanism of endogamy' (Dr. Babasaheb Ambedkar Writing and Speeches 2014 p. 4). Endogamy strictly controls the sexuality of women which is followed in Hindu culture. It shows how the caste system uses women to safeguard the caste hierarchy within the notion of purity and impurity and makes a woman regulate her sexuality in the name of honour and virtue. Furthermore, Manusmriti supports these arguments by snatching away all kinds of freedom from women in the process of making them dependent on their male partners in the household (Ambedkar, 2014, p. 429-30). Similar roles for women can be seen in Kautilya, which considered women as property (Aloysius, Mangubhai, \& Lee, 2011, p. 26). The very notion of seeing women as property, as keepers of family and caste honour, make them vulnerable victims of caste, communal, and ethnic violence. ${ }^{1}$ In addition, on an average, the most read and celebrated epics stories of Mahabharata and Ramayana portrayed Dalit women as Asura, or those who attempted to break religious norms and faced retribution. Vizia Bharati (2019) cites the characters of Matanga Kanyas, Tadaka, Shurpankha, and Ayaomukhi, who expressed their interests towards Kshatriy a varna rulers and were punished with chopping off of their noses, or ears and even killed. 
Similar atrocious punishments persist in modern India against lower caste women. For instance, the religiously sanctioned practice of Devadasi (servant of God) system for Dalit women, still exists in some parts of rural India. Savi Sawarkar (2019) argues that it is a heinous 'psychotic perversion'. In the Devadasi system, a Dalit woman is made to 'give' herself to the service of God. However, local priests who proclaimed themselves as agents of God, sexually exploit Dalit girls on a regular basis and turn them into objects of their desires, while perpetrating the notion that these girls do not have any kind of rights on their own bodies. Such a practice creates a double sense of disgust as 'untouchable' and 'women' among the victims. Sawarkar (2019) observes that many priests have made it a daily routine of physically abusing these women with a notion that it is their 'right to have pleasure' over the 'untouchable body of women' (Bharati, Arya \& Rathore, 2019, p. 122-24). In other words, it is religiously sanctioned sexual slavery, which stigmatizes a Dalit woman till the end of her life.

The context of sexual domination paradigms: the control over women's sexuality in Brahminical patriarchy and the concurrent discourse of 'honour' and 'shame' with the specific power, force, and authority allowed dominant caste males to exercise control over Dalit women's bodies. Ironically, the perception of Dalit women bodies as 'polluted' and 'untouchable' become 'touchable' during sexual violence (Aloysius, Mangubhai, \& Lee, 2011, p.177-78). However, the worst aspect of repression in rape is due to its social meaning i.e. izzat lutna (robbing honour) in Indian society. After rape, a woman's body becomes an unmarriageable body that is ostracized from the social relations process. Therefore, it is considered as one of the most heinous punishments for a woman.

According to Ruth Manorama, 'certain forms of violence are traditionally reserved for Dalit women: extreme filthy verbal abuse and sexual epithets, naked parading, dismemberment, pulling off teeth and nails, and violence including murder after proclaiming witchcraft, and many more' (Manorama, Channa \&Mencher, 2013, p. 263). Laura Brueck (2012) argues that upper caste men's usage of Dalit women's bodies is a way of controlling and humiliating Dalit men. 'The prime reason behind this consideration is that any attack on a Dalit woman is an attack on the Dalit community and their men's masculinity' (the ability of a man to protect his wife and other women in the family who are dependent on him). On a regular basis, a collective effort of violence by the higher castes to threaten Dalit women is obvious (Brueck,2012, p. 226). The importance of masculinity and its related considerations are better explained by Jean-Paul Sartre as 'a man feels himself more of a man when he is imposing himself and making others the instrument of his will. 'It gives him 'incomparable pleasure' (Roul, 2016, p. 111). In cases of caste violence and rape, the perpetrators get similar pleasure, when they instigate violence. The supremacy of dominant caste men on Dalit women's sexuality also exposes the caste-obsessed nature of the state and society. For instance, retribution for violation of caste norms includes caste violence which includes rape, as part of feudal punishment. Thus, crimes such as rape often amount to attaining power, dominance, and control rather than mere sexual fulfilments. Certainly, the sexual violence on Dalit women is the penalty of their assertion against the hegemony of the dominant caste (WSS, 2015, p. 48). 


\section{Demystifying Rape}

It is believed that rape is committed against women irrespective of their social identities. 'Rape is rape' (Raphael, 2013) be it outside or inside the room, attempted by an individual or a group, occurs intentionally or unintentionally, but it is a crime against a woman due to her sexuality (Diwakar, 2019, p. 63-64). A committee set up in 1979 on the elimination of discrimination against women primarily drew attention towards all kinds of gender-based violence. It observed that women faced violence not merely for their female sexual characteristics but also due to deprivation of equal status, violation of their dignity and human rights, which impacted on their overall growth. Therefore, one has to distinguish between rape as violence on female sexuality, or as a political tool to humiliate the enemy group or community. Apart from sexual violation of the human body, there are other definitions of rape which acknowledge patriarchal and intersectional structures of society that contribute to such incidents. For example, within feminism, the radical feminists have come up with two major categorizations of rape:'violence is sex' and 'violence is not sex' (Price, 2009, 12-14). According to Kathleen Barry (1984) the definition of crimes against women consider those acts of violence which are directed towards women due to their female sexual characteristics; in which men treat women as an object of their sexual desire. Barry's definition contrasts with the idea of power, dominance, and control. However, Sanday (1981) has observed that the sexual act of rape is not merely about sexual gratification of male, but the deployment of the penis as symbolic masculine social power and dominance (Ibid). Another understanding suggests women as the property of males in the family. The argument that rape is not about a woman's consent or will, instead a property crime against men...has been emphasized by Susan Brownmiller (1975, p.17-18). She explains that in the nineteenth century, married women were considered by law to be the property of their husbands. And if a woman is not married, she is a property of her father (Brownmiller, 1975, p. 63-65).

Clark and Lewis (1977) mention that rape is snatching someone's sexual property with whom the rapist does not have any relationship. It also is seen as a crime against the honour of the family, community in order to humiliate, degrade, and stigmatize the community in public domain. In both the theorization, the role of power dynamic is crucial to understand how a woman's sexuality is used as a tool to avert the demands and assertions made by the community at large. Along with that, feminists mostly discuss rape in the form of gender-based violence due to the oppressive structure of patriarchy. Still, there is a need to widen this understanding through intersectional structures, with special considerations about the particular identities of caste, religion, and ethnicity as reasons for rape in India. However, sexual violence incidents against Dalit women need an intersectional and inter-disciplinary framework. When a Dalit woman is raped, it is not a sexual act that is committed on one individual but an act of violation of the human rights of the social group that she belongs to. What is being asserted here is not merely male superiority, but caste, and community superiority as well. The upper caste men or their communities as a whole violate all norms of 'pollution' (impurity) when they touch the body of a Dalit woman. Ironically, the people who shun even the shadow of the Dalit feel no violation of their purity when they rape a Dalit woman. It is not a matter of purity and pollution; it is a matter of exploitation and extraction of labour and services at the cheapest possible terms from the Dalits. It is therefore crucial to see the act as political rather than sexual; it is a direct violation of human rights and dignity (Channa, 2013, p. 267). 


\section{Situating the Perpetrator and the Victim/Survivor}

To identify the causal factors of sexual violence on Dalit women, one needs to look at the context of the social status of the perpetrator and the victim. In most cases, Dalit women have mentioned that the perpetrators were either landlords or having functional economic and political clout in the society or state institutions. ${ }^{2}$ On the other hand, the victim Dalit women were mostly engaged as agricultural laborers, midwives, or domestic workers in upper-caste Hindu houses. Because of Dalit women's economic dependence on perpetrators, they get a lot of chances to harass them. According to an AIDMAM report, 'the non-Dalit first occupies the land of Dalit and then seeks sexual benefits from the mother, daughter, or daughter-in-law. Sometimes the non-Dalits get the Dalit men drunk and so they don't know what's happening with the women in the house $(2018,12)$. Along with that, the role of state and non-state actors such as police, local political ruling parties, panchayats, political leaders, medical officers, goons, and blatant and subtle forms of support from other dominant caste people becomes prominent in the perpetuation of violence (Aloysius, Mangubhai, \& Lee, 2011).

In some cases, a family member also helps the perpetrator. The two case studies discussed in this paper highlight the role of state and non-state actors directly and indirectly moderating such instigations. In the Bhagana rape case, the perpetrators (belonginig to the dominant Jat community) were politically influential and represented in the state and administrative mechanisms. They had hundreds of acres of land and were economically powerful too. They also influenced the Panchayat and police machinery. In comparison, the Chamar and Dhanuks victims were from the scheduled caste community. They were landless labourers and worked in the fields of Jats. Similarly, in the second case in Alwar, Gujjars were the dominant caste who influenced the state political and local administration machinery in Rajasthan.

\section{Land as Contested Space: Bhagana Rape Case}

The incidents of rape on Dalit women by dominant caste groups have been on the rise in Haryana. According to NCRB data, the numbers of rape cases against Dalit girls or women rose from 1,346 in 2009 to 2,536 in 2016 an increase of 88.4 percent nationally, while in Haryana they rose by a whopping 167 percent (Teltumbde, 2018, p. 167). According to the AIDMAM and National Tribunal reports the maximum number of sexual violence cases came from Haryana, followed by Rajasthan and Uttar Pradesh (AIDMAM \& NCHDR, 2018, p. 27). The state is also notorious for feudal practices such as involvement of khap panchayats (community courts) in social affairs as a 'moral cornerstone' of communities' justice delivery mechanism. Most of the crimes involve suppression of Dalits by the dominant castes and the use of caste and misogynistic language, followed by dehumanization and objectification of Dalit women's bodies. In addition to glamorization of violence and masculinity, the justification of caste, class, and gender hierarchies, have not been able to help in the preservation of law and order and overall stability in the state. The failure of land reforms in the state has worked to the advantage of the Jat community enabling their economic and social dominance as also overwhelming hold over political power.

With eighty percent of all land in the state being owned by Jats, they are the only caste in Haryana to corner state benefits at large while marginalized and backward classes remain deprived. They have been able to exercise undoubted control over 
the state machinery as well with their presence in majority of formal and informal institutions. As a result they have been seen exercising their caste power over other castes and social groups with impunity. Not surprisingly, the sexual exploitation of Dalit women and girls is considered by Jats a privilege which they can easily access. Apart from several forms of dominance such as major ownership of productive lands, the Jats also control several common village assets such as grazing lands, wastelands used for defecation and burial of dead animals, and lands such as playgrounds and chaupals (used for community meetings) which are developed with public funds. Due to the lack of free access to such spaces, Dalits have been dependent on Jat landowners for economic support. Therefore, it is quite common for Jats to 'enforce' social and economic boycotts against Dalits when they try to assert their rights to public assets such as common land. Against this backdrop of caste conflicts and simmering differences, rape incidents of Dalit women are embedded in the nature of violence so as to gain social control over them. These incidents cannot be seen in isolation but are a continuum of pre-existing social tensions among various castes.

A case in point is the Bhagana rape case of 2014. Bhagana is a small village in Hisar district. The Jat community dominates the village while Chamars and Dhanuks, representing the lower castes, are Dalits. Unlike Jats, Dalits are mostly landless wage labourers employed in fields owned by the dominant caste. On the night of $23^{\text {rd }} \mathrm{March}$ 2014, four minor Dalit girls went out of their houses to answer nature's call. Five men of the Jat community, who had been stalking them for a long time, abducted the girls by dragging them into a car. They sedated and gang-raped the girls and then dumped about $170 \mathrm{kms}$ away near Bhatinda railway station in the neighbouring state of Punjab. Upon their daughters' sudden disappearance, the parents of the girls approached the village sarpanch (village head), who was also a Jat. Instead of taking the incident seriously and helping the parents file a police complaint, the sarpanch tried to pass off the incident as a case of elopement. On the persistence of parents, he took the missing girls' parents and relatives to Bhatinda railway where the girls were found. On their way back, the sarpanch accompanied the girls in a car while their relatives were asked to take the bus. This was allegedly done to intimidate the girls throughout the journey asking them to forget the incident and warning them of dire consequences for their families in case they went ahead with police complaint. All the while, the sarpanch, upper caste people, and police insisted that the incident was a case of elopement alleging that one of the victims had an affair with one of the accused persons and that the girls were raking up the issue to get compensation from government.

Nonetheless, the girls and their families filed a police complaint following which the girls under went a medical examination confirming rape and physical assault. Although the police were initially reluctant to file a case and proceed further, they could not resist any further due to pressure from families and Dalit activists.

A sting operation by a leading news magazine Tehelka later found that the entire episode had been carefully planned as a means to settle scores with parents of one of the victims whose father had taken on the sarpanch by lodging a police complaint against him. The father worked as a daily wage labourer in the house of the sarpanch. Once, he was beatenup on the issue of wages. He lodged a First Information Report (FIR) against the sarpanch, but the police did not take any action against them. The sarpanch and his relatives threatened to 'teach a lesson' to the daily wager for having gone to the police station against them. After a month, the gangrape incident happened. Here, sexual violence needs to be seen in the background of simmering tensions 
between the Dalit and Jat communities. The incident of rape was the consequence of a prior conflict. Another among the several simmering issues between Dalits and Jats in the village pertained to the fundamental right to use and access the shamilat-deh (common land) in Bhagana. The authority for distribution of common land is vested in the Panchayat. The Amendment Act of Punjab Village Common Land (Regulation), October 2009 states:

A Panchayat may, gift, sell, exchange or lease the land in Shamilat-deh vested in it under this Act to such persons including members of scheduled caste and backward classes on such terms and conditions, as may be prescribed' (Association for Democratic Rights [AFDR], People's Union Democratic Rights [PUDR], \&Women against Sexual Violence and State Repression [WSS], 2014, p.4.).

In 2012, 280 acres of common land was under the authority of the village Panchayat. Out of the total, sixty acres was distributed among villagers through auction. The Jats dominated the Panchayat and got access to more land. They deliberately planted trees on the common land to stop Dalit accessibility to the area. They also allegedly collected Rs 1000 rupees per family for plot allotment. While the sarpanch stated that they had already allotted 123 plots to Dalit families, the Dalits resisted the allotment as the plots given to them were earlier used as burial grounds by upper caste people. Since Dalits are mostly landless labourers and they have livestock that grazed on the common land, they had no grazing land left after it was allotted to others following the auction. This affected their livelihood. The PUDR report mentions that the Dalits were raising their voice to seek redistribution of common land. When the Dalits started raising their voice against injustice, the Jats began to prohibit them from accessing public spheres. Subsequently, Dalits started protesting against it. On $21^{\text {st }}$ March 2014, the Dalits filed a case against the Jats' encroachment on common land. However, the judiciary bypassed the issue saying that 'the case comes under the Panchayat's authority; and the judiciary has no role to play' (PUDR, 2014, p. 6-7).

The Dalits in the village had also been demanding a change in the name of a village square from 'chamar chowk' to 'Ambedkar Chowk' and wanted to install a statue of Dr. Ambedkar there. Yet another demand was related to a playground. After the rape incident, 137 families of the chamar community went to Delhi for holding a demonstration in their quest for justice. They organized under the banner of Bhagana Kaand Sangharsh Samiti (Bhagana episode struggle committee) and demanded justice for the rape victims and socially boycotted villagers. However, the state government and the central regime took no action.

In this case, the dominant caste used rape as an instrument of caste shame and humiliation. According to Prem Chowdhary (2010), because of persisting caste boundaries and notions of purity, the upper-caste ensures control over women's sexuality. However, in the case of Dalit women, their bodies are seen as a 'site of dishonour, revenge, and subordination'. Attempting rape on Dalit women becomes a symbolic mechanism of perpetuating subjugation. Rape, thus, is relational violence because it is connected to family and community honour. ${ }^{3}$

Interestingly, the culprits do not consider rape as violence until they face any resistance, and are in a position to proclaim that it (raping) is their right. On the other hand, the victims and even their families and community as a whole are subjected to all sorts of humiliation as a collective punishment (Baxi, 2014, p. 28). 


\section{Alwar Gang Rape Case}

When rape is used as an instrument to impose power, or reflect the powerful position of influential people in society, it is considered 'power rape'. According to Geetha Mukherjee(1983), "when a woman is raped under economic domination, or influence, or control, or authority, it includes all kinds of legal and illegal domination by the perpetrator who is holding power in a state or non-state mechanism through which he shall deem to commit rape' (Baxi, 2014, p. 34-35). Baxi (2014) argues that in the case of Bhanwari Devi (1992), men of the dominant Gujjar community raped her as she had ventured to stop a child marriage in their family. This action was considered by Gujjars as humiliating as a lower caste woman had dared to question their customs. During the long-drawn legal battle for justice, a sessions judge reportedly said 'it's impossible for upper-caste men to rape a lower caste woman' (Shukla, 2006). The judgment mentioned Bhanwari Devi as 'un-rape-able' based on her social location vis-à-vis the age and caste location of perpetrators. Nonetheless, the incident led to the introduction of a law on sexual harassment even though incidents of power rape have not stopped since.

A more recent instance of 'power rape' is the gang rape of a married Dalit woman on $26^{\text {th }}$ April 2019 in Rajasthan's Alwar district. A Dalit couple was riding a motorcycle at around $3 \mathrm{pm}$, when they were stopped by six men on two motorcycles. As the men turned aggressive and violent, the couple pleaded with them that they were married and even tried to prove their credentials by giving their village name and contacting relatives but to no avail. Once it became clear that they were Dalits, the attackers seized their vehicle and forced them to an isolated spot and took turns raping the woman. The victim recalled that the attackers first asked their names, fathers' name, marital status, and their caste too. When they disclosed that they were 'Dalits and a married couple,' one of the attackers said, 'what can a Dalit do to us' (Dayal, 2019). They even video-recorded the gruesome act. Once they were done, the accused forced the couple into a sexual act and filmed that too. The couple was let off after two hours. They also took Rs 2000 from the husand and warned the couple against reporting or filing a complaint about the incident or they would circulate the video on social media.

However, two days later the perpetrators began black mailing the couple asking Rs 10000 , which they were unable to pay and sought the help of relatives. With the support of relatives the couple reported the incident to the police but no action was taken. Meanwhile, the perpetrators went ahead and circulated the videos on social media. It was after the relatives showed the video recording of the incident to the police on May 4, 2019, that all the six accused were arrested (Scroll, 2019). The woman meanwhile said that she had received immense support from her husband and in-laws in resuming normal life thereafter. In hindsight, she wondered if her caste identity was the sole reason behind the rape as the perpetrators were confident that no harm could come to them due to their superior and dominant caste status in the area.

The incident also exposes the unwillingness on the part of state machinery to take up issues of Dalits, particularly Dalit women. It also draws attention to vote bank politics as the caste considerations of the accused and their dominant status was hampering justice for the Dalit woman. For the police, the woman's issues had become secondary and it was only after the videos of sexual violence got viral on social media that they were forced to take action against the upper caste accused. (Dayal, 2019). 
The incident reflects how rape is not merely sexual assault but a form of 'sexual terrorism', used by patriarchal and caste-obsessed people to subjugate the Dalit women in particular and community in general. Cheris Kramarae (1986) defines sexual terrorism as part of a broader political project which hinges on the total appropriation of women's bodies. Such trauma and suffering have become 'routine' in Dalit women's lives. The persistence of violence against Dalit women, the escalation of its scale, method, and intensity remain unnoticed and unaddressed. The similarity that can be drawn between Bhagana and Alwar cases is that both were results of intentional and targeted caste violence. The issues of distribution of common land, resource usage, and caste dominance had created ground for caste-based sexual violence. In both cases, Dalit women were the major victims of atrocities and bore the brunt of casteism.

\section{Conclusion}

Violence against women is one of the major challenges towards achieving an equal and just society. Any form of violence against women is unacceptable. Among the several acts of violence, rape is the most heinious act against a woman. It is not merely a non-consensual sexual act forced on a woman's body but is loaded with several social, cultural, and political considerations associated with women's bodies. This paper discusses how forced sex is a used as a significant tool to suppress the rights and dignity of not just Dalit women, but the community as a whole. It also highlights the patriarchal, and hierarchical caste and class structures which legitimize sexual crime against lower caste women. The rape of a Dalit woman revolves around the issues of both patriarchal and Brahminical norms. It is therefore pivotal to note that caste is the dominant factor in case of incidents of sex crimes against Dalit women.

In most cases rape becomes the consequence or the resultant end of several causal factors such as land disputes, factional rivalry, and above all caste dominance due to deeply embedded discriminatory behaviour sanctioned by religion. Both the Alwar and Bhagana cases throw light on the apathy of the state authorities in ensuring justice to victims and survivors. Rather than looking into the enormity of the violence against an individual, these Reveled how state institutions characterize women by their caste identity.

The notion of individuality disappears in the cases of Dalit women. Caste-biased rape is not only a mere non-consensual physical act of violence but is also a festering wound on the individual's psyche as also that of her community. As memories of such events and trauma haunt Dalit women they live in perpetual fear, which adversely affects their future aspirations. Hence, rapes of Dalit women need to be tackled with the human rights approach so that their concerns are addressed more inclusively and substantially. Also, in order to prevent violence on Dalit women there is a need for 'substantive' justice rather than a 'punitive' one. It can only be possible when the state, civil society, academia, and mainstream media collectively start to address their issues without prejudiced minds and institutional support is provided in a holistic manner. 


\section{References}

AFDR, PUDR, \& WSS. (2014). Sexual assault on four girls in Haryana: In the context of Dalits Rights on common land. Delhi: PUDR (pp. 01-10)

Agrawal, P. (2012). Savarkar, Surat and Draupadi: Legitimizing Rape as a Political Weapon. In 977095107757495129 K. Panjabi (Author), Women contesting culture: Changing frames of gender politics in India (pp. 259-273). Kolkata: Stree.

AIDMAM-NCDHR (2018). Voices against caste impunity: narratives of Dalit women in India. Study Report, National Campaign for Dalit Human Rights, New Delhi.

Aloysius, I., Mangubhai, J. P., \& Lee, J. G. (2011). Dalit women speak out: Caste, Class and Gender Violence in India. Delhi: Zubban.

Ambedkar, B., Dr. (2014). Castes in India: Their Mechanism, Genesis and Development. In V. Moon (Com.), Dr. Babasaheb Ambedkar Writings and Speeches (Vol. I, pp. 3-22). New Delhi`: Dr. Ambedkar Foundation (Ministry of Social Justice \& Empowerment, Govt. of India).

Ambedkar, B., Dr. (2014). Thoughts on Lingustic State. In V. Moon (Com.), Dr. Babasaheb Ambedkar Writings and Speeches (Vol. I, pp. 136-171). New Delhi`: Dr. Ambedkar Foundation (Ministry of Social Justice \& Empowerment, Govt. of India).

Ambedkar, B.R. (2014). The women and the counter revolution. In V. Moon (Ed.), Dr. Babasaheb Ambedkar Writings and Speeches (Vol. 3, pp. 427-433). New Delhi, Delhi: Dr Ambedkar Foundation.

Arya, S., \& Rathore, A.S. (Eds.) (2019). Dalit Feminist theory: A reader. New York: Routledge. Barry, K. (1984). Female sexual slavery. New York u.a.: New York Univ. Pr.

Baxi, P. (2014). Public secrets of law: Rape trials in India. New Delhi, India: Oxford University Press.

Bharati, V. (2019). Vilifying Dalitwomen: Epics and aesthetics. In A. S. Rathore \& S. Arya (Eds.) Dalitfeminist theory: a reader (pp. 117-130). New York: Routledge.

Brownmiller, S. (1975). Against our will: Men, women and rape. New York: Faweet Columbia.

Brueck, L. (2012). At the intersection of gender and caste: Rescripting rape in Dalitfeminist narratives. In A. Loombo\& R. A. Lukose (Eds.) South Asian feminism (pp. 224-43). Durham: Duke University Press.

Brueck, L. (2014). Writing Resistance: The Rhetorical Imagination of Hindi Dalit Literature. New York: Columbia University Press.

Chakravarti, U. (1993). Conceptualising Brahmanical patriarchy in early India: Gender, caste, class and state. Economic and Political Weekly,28(14), 579-585.

Chakravarti, U. (2006). Gendering caste: Through a feminist lens. Kolkata: Stree.

Channa, S.M. (2013). Commentary on Ruth Manorama's Presentation at the Fourth World Conference on Women. In S.M. Channa\& J.P. Mencher (Eds.) Life as a Dalit: Views from the bottom on caste in India (pp. 261-267). New Delhi: Sage Publication.

Chowdhary, Prem (2010)Redeeming honour through violence:Unraveling the concept and its applications, New Delhi: CEQUIN Retrieved from http://cequinindia.org/images/ ResourcesItem/Pdf/Honour\%20killings\%20by\%20Prem\%20Choudhury.pdf.

Clark, L. M., \& Lewis, D. J. (1977). Rape: The price of coercive sexuality. Toronto: Women's Press.

Darapuri, S. (2017). Social Exclusion on Dalit Women. In Y.C. Rao \& S. Bhattacharya (Eds.) The past of the outcaste: Reading in Dalit History (pp. 441-50). New Delhi, Delhi: Orient Blackswan. 
Dayal, S. (2019, May 21). We said we are Dalits, they said what Dalit can do to us: Gangrape Victim. The Indian Express. Retrieved from http://epaper.indianexpress.com/2163729/ Delhi/May-21-2019\#page/1/1

Diwakar, J. (2019). Legitimising rape: Exclusion of sexual violence against Dalit women. In P. Singh (Ed.) Contouring exclusion: Manifestation and implication (pp. 64-84). New Delhi, Delhi: Lokmitra Publication.

Dutta, S. S. (2019, May 19). Four dalit women are raped everyday, with several on multiple occasions. The Indian Express. Retrieved from https://www.newindianexpress.com/ thesundaystandard/2019/may/19/four-Dalit-women-are-raped-every-day-with-several-onmultiple-occasions-1978741.html

Galtung, J. (1990). Culture Violence. Journal of Peace and Research, 27, 291-305. Retrieved from https://www.galtung-institut.de/wp-content/uploads/2015/12/Cultural-ViolenceGaltung.pdf.

Kramare, C. (1986). Speech Crimes Which Law Cannot Reach. In 976992956757436185 S. Bermner (Ed.), Proceedings of Women and Language Conference (pp. 84-95). Berkeley: University of California.

Kumar, V. (2020). Nature of violence against Dalitwomen. In J. Atwal \& I. Flessenkämper(Eds.) Gender and violence in historical and contemporary perspectives: Situating India (pp. 141-52). New York: Routledge India.

Paik, S. (2018). The rise of new Dalit Women in Indian historiography. History Compass, 16(10), 01-14.

Price, L. S. (2009). Feminist frameworks: Building theory on violence against women. New Delhi: Aakar Books.

Raj, K. (1995). Justice Denied [Editorial]. Economic and Political Weekly, 30(47), 2967-2968.

Rao, A. (2011). Violence and humanity: or, vulnerability as political subjectivity. Social Research, 78(2), 607-632.

Raphael, J. (2013). Rape is Rape: How Denial, Distortion, and Victim Blaming are Fueling a Hidden Acquaintance Rape Crisis. U.S.A: Lawrence Hill Books.

Rege, S. (2013). Against the madness of Manu: B.R. Ambedkar's writings on Brahminical patriarchy. New Delhi, Delhi: Navayana Publication.

Roul, K. (2016). Violence and Political Theory. In S. Nayak (Ed.) Combating violence against women: A reality in the making. New Delhi, Delhi: Kalpaz.

Sanday, P. R. (1981). The Socio-Cultural Context of Rape: A Cross-Cultural Study. Journal of Social Issues, 37(4), 5-27. doi:10.1111/j.1540-4560.1981.tb01068.x

Scroll.in (2019, May 8). Rajasthan: Dalitwoman in Alwar allegedly gang-raped. Scroll. inRetrieved from https://scroll.in/latest/922744/rajasthan-Dalit-woman-in-alwar-allegedlygang-raped-in-front-of-her-husband

Shukla, R. (2006). Judicial pronouncements and caste. Economic and Political Weekly, 41(42), 4403-4406.

Teltumbde, A. (2018). Republic of caste. New Delhi, Delhi: Navayana Publication.

WSS(2015). Rape as atrocity in contemporary Haryana. Economic and Political Weekly, 50(44), $47-56$.

Yengde, S. (2019). Caste matter. New York: Penguin. 


\section{Endnotes}

1 According to Adama Dieng, representative of UN on sexual violence in conflicts, sexual violence became a 'tool of dehumanization and shame' and 'a weapon of punishment and persecution'. See: Edith M. Lederer, 'Sexual Violence being used as Terror Tactics,' The Times of India (Delhi), May 16, 2017. Susan Brownmiller also stated the meaning of rape as the violent act against another person and the property in the context of war. See: Susan Brownmiller, Against our will: Men, women and rape (New York: Fawcett Columbia., 1975), 186.

2 If we look the previous caste atrocities cases, we see that perpetrators have invariably been from higher castes. In the Karamchedu massacre (1985) in Andhra Pradesh, the perpetrators belongedtotheKammaslandlord community, who had a hold in politics and administrative posts and a dominant position among other castes. In theBhanwari Devi case in Rajasthan (1992), Gujjars were the dominant community in Bhaterivillage.They gang rapedBhanwaridevi in front of herhusband. IntheShivapati case (1994) and Anita Kumari case in Uttar Pradesh a Dalit woman wadraped by adominant caste community male. In the case of Khairlanjicasein Maharashtra (2006) the offenders were from Kunabi and Kalar caste group. They were also the dominant castes in Khairlanji village. In the case of Mirchapur (2010) and Bhagana (2014) in Haryana the perpetrators werefromJat community.

3 The ideology of honour is highlighted in the gendered notion of inequality and hierarchy. Men and women both embody honour, but the woman is the repository and men are the regulator of honour. Thus, a woman's honour is associate with family and community honour. So, if a woman is 'dishonoured' by any mechanism, then her family or community can never regain that honour. See: PremChowdhary, Redeeming honour through violence:Unraveling the concept and its applications(New Delhi: CEQUIN, 2010), http://cequinindia.org/images/ ResourcesItem/Pdf/Honour\%20killings\%20by\%20Prem\%20Choudhury.pdf. 